\title{
The Ideological Coalition Model is The Strategy for Strengthening Presidential Systems in Indonesia
}

\author{
$1^{\text {st }}$ Restu Rahmawati ${ }^{1}, 2^{\text {nd }}$ Firman, Firman ${ }^{2}$ \\ \{restu.rahmawati3@gmail.com ${ }^{1}$, firman@uta45jakarta.ac.id ${ }^{2}$ \} \\ University of 17 Agustus 1945 Jakarta, Jalan Sunter Permai Raya, North Jakarta ${ }^{1,2}$
}

\begin{abstract}
This paper examines the impact of implementing an ideological coalition model for strengthening presidential systems in Indonesia. The reason for raising this issue is because the current application of the parliamentary system coalition in the presidential system in Indonesia is causing problems in the legislative body so that the debate in parliament about a government policy is no longer concerned with the interests of the people but rather that it highlights the opposing attitude of the government. Parliamentary system coalition, if implemented in a presidential system, will only prioritize political interests, so an ideological coalition model is needed. The methodology used is a literature study on the ideology coalition model and the writer will look for aspects of the impact of the ideology coalition model for strengthening presidential systems in Indonesia in this modern democratic era. The result shows that ideological coalition is needed in the life of the nation and state because ideology is the basis of political party platforms to build a shared vision and mission in organizing the state so that this ideological coalition can strengthen political institutions in the presidential system. Applications of this study can be used for the government, legislative members, teachers, and students. In this research, the model of ideological coalition model for strengthening presidential systems in Indonesia is presented in a comprehensive and complete manner.
\end{abstract}

Keywords: presidential systems, ideological coalition, strengthening presidential systems

\section{Introduction}

After the end of the 2014legis lative elections, several notes can be seen about the political constellation that changes at the national level such as the increase in the Gerindra Party's vote which reached 11.1 percent of the vote. Then the Nas ional Demokrat (Nas dem) Party also agreed that the votes were fairly high at around 6.72 percent. Although the Nasdem Party is a new party, it can compete with old parties. The Indonesian Democratic Party of Struggle has the largest number of votes reaching $23,681,471$ or $18.95 \%$ not fulfilling the requirements to carry the presidential candidate himself, following the legal 25 percent requirement so that it can be used to save the presidential candidate himself.

Referring to the explanation above, political parties must form coalitions with other parties so that they can meet the 25 percent requirement to carry the presidential candidates. The requirement for a political party to form a coalition is the result of Law No. 24 of 2009 concerning presidential elections which require 25 percent of national valid votes or 20 percent of seats in the DPR. The phenomenon of party coalition in Indonesia is an important record in the history of the Indonesian state and records the presidential and vice-presidential elections. In the process of building a coalition, it is seen that the elite determine interests for the pers onal and party interests of the community as the constituents. This attitude was the beginning that injured the strengthening of the party system in Indonesia. 
With the condition of the coalition that does not reflect the interests of the community, it will make people no longer trust political parties, even though political parties determine the quality of democracy produced. The coalition of political parties in Indonesia can be seen during the 1999 elections such as they struggle in the pivot coalition that won the PDI Perjuangan as the winner of the election (Lindsey, 2001). Likewise, the coalition in the 2004 elections, the Democratic Party with a coalition with several political parties managed to win a pair of presidential candidates who were promoted by the GolkarParty as the party winning the election and succeeded in controlling the legis lature. This coalition can be seen as a strategy to encourage its policies in the legis lature (Asrinaldi, 2013). This coalition that illustrates the journey of democracy in Indonesia proves the fragmentation of interests discussed in Indonesia.

In Indonesia, which adheres to the presidential and party muti system, there is a tendency for an ongoing coalition to threaten the democratic process. Why is that? Because the coalition with multi-parties is full of polarization of interes ts so that it has an impact on the stability of government administration. Als o, not a few fragments occur in legislative ins titutions that are also elected by the people (Dahl, Shapiro, \& Cheibub, 2003). The impact of the fragmentation is the tug-of-war between the executive and the legislature. If this happens there will be a political deadlock in the administration of government power (Asrinaldi, 2013). Ideally, a presidential systemplaces a strong and autonomous position of the president in action. Even if there is a debate between the executive and legislative bodies, it is no more as a form of implementation of checks and balances mechanisms. However, what happened was that the president was held hostageby the mis sion of the political parties that supported him so that he was not autonomous in acting. Even the presidential system practiced in Indonesia is not an actual presidential sy stem. There is still a blurring of substance-related to the implementation of this presidential system with the practice of a coalition of parliamentary models being implemented (Asrinaldi, 2013). Therefore there needs to be a seriou s effort from the state to restore the nature of this presidential sys tem and the national coalition model is also important to be applied to strengthen the presidential system.

\section{Methods}

On the basis of such an analysis, the writer will seek information through a literature study on the ideology coalition model and the writer will look for aspects of the impact of the ideology coalition model for strengthening presidential systems in Indonesia in this modern democratic era.

\section{The Ideological Coalition Model is The Strategy for Strengthening Presidential Systems in Indonesia}

Several weaknesses can be explained about the coalition of the parliamentary model being implemented. First, the most fundamental thing due to the ongoing coalition of political parties is the increasingly obscure nature of the function of the presidential system in the political system. This blurring can be seen from the independence of the president in making policy because he must consider his coalition partners. Even though the president in the presidential systemis not directly elected by members of the legis lature. This should ideally be considered by an elected president. Especially if the president is supported by a majority of the people's votes. That is, the president gets strong legitimacy compared to elected 
legislators. Thus, the president must think about the responsibility to the community (Asrinaldi, 2013).

Another impact is also due to the emergence of coalition practices that use this parliamentary model is not the optimal function of the legislature. This tendency can be seen from the development of a political culture that becomes the character of the lower class of society but has spread so that it becomes a party elite culture. This can be seen from the formation of a patron-client (Keefer \& Vlaicu, 2008; Khan, 2005; Villarreal, 2002) in a political system that no longer occurs at the grassroots level.

A politicalculture like this has become an inseparable part of political practices within the party. As it is known, that the party elite who sit in the government formed by the coalition consists of those who become leaders in political politik (Almond \& Verba, 2015; Fassin, 2007; Hampson, Held, McGrew, Goldblatt, \& Perraton, 1999). This position is not uncommon to be a dilemma for members of political parties in the legis lature. Even if there are policies that are made and are "at odds" with the way of thinking of party members in the legislative body, then the debates that occur tend not to belong considering the ministers in the cabinet are senior political parties. So clearly, the reluctance to debate the draft policy by members of the DPR has caused the implementation of the functions of the legis lative body to be suboptimal.

To strengthen the presidential system, in addition to strengthening the function of political parties, political party coalitions must also aim strategically, namely coalitions that are built to fulfill the interests of the vision and ideology of political parties. The purpose of this strategic ideological coalition is for the purpose of fulfilling people's expectations. An ideologicalcoalition is needed to be a platform for political parties to build a shared vision and mis sion in org anizing the country. Likewise in the coalition process in Indonesia, there needs to be a concern. The shared vision in developing Indonesia was precisely formulated after the victory in forming a government. The coalition participant party tried to adjust its vision with the party which became the main axis of the party. Supposedly, the determination of a shared vision in developing Indonesia was formulated at the outset by carrying out the interests of the people and fulfilling people's expectations. Ideology, in this case, is the ideology of nationality possessed by political parties.

In addition, in forming a coalition based on ideology will strengthen governance. The nature of the coalition its elf forms a strong, independent (autonomous), and durable government. A strong governmentcan be interpreted as a government capable of creating and implementing its policies without fear of rejection or resistance in parliament. In fact, he also stres sed that political parties are required to understand the meaning of the coalition government as a mutually conditional and non-negotiable from a multi-party system.

Many parties believe that if the function of this political party can run well, then this presidential systemcan be implemented in accordance with community expectations. How not, one of the functions of the party is a means to control conflicts that occur in the administration of government power. That is, as long as members of political parties in the legislature are aware of this function, of course, the orientation of their power is used to represent the interests of society more prominent than other aspects. However, this is difficult because of the dominance of party interests so competition between the legislative and executive institutions is inevitable. Likewise with the nature of the function of recruiting new members carried out by political (Coller, Cordero, \& Echavarren, 2017). Ideally, political 
parties should be able to look for candidates who have good oral competence and integrity. During this time, many parties highlight this problem. The party's recruitment was carried out so that it neglected as pects of moral competence and integrity. As a result, political parties only offer party cadres who are less qualified.

In Indonesia, which adheres to the presidential and party muti system, there is a tendency for an ongoing coalition to threaten the democratic process. Why is that? Because the coalition with multi-parties is full of polarization of interests so that it has an impact on the stability of government administration. In addition, not a few fragments occur in the legis lature which is also elected by the people. The impact of the fragmentation is the tug-of-war between the executive and the legislature. If this happens then there will be a political deadlock in the administration of government power. Ideally, a presidential system places a strong and autonomous position on the president in action.

Even if there is a debate between the executive and legislativebodies, it is no more as a form of implementation of checks and balances mechanis ms. However, what happened was that the president was held hostage by the mis sion of the political parties that supported him so that he was not autonomous in acting. Even the presidential systempracticed in Indonesia is not an actual presidential system. There is still a blurring of substance-related to the implementation of this presidential system with the practice of the coalition of the parliamentary model being implemented. Therefore there needs to be a serious effort from the state to res tore the nature of this presidential system and the national coalition model is also important to be applied to strengthen the presidential system.

Based on the empirical problem and theoretical problem described above, Indonesia needs an ideologicalcoalition model in the life of the nation and statebecause ideology is the bas is of platforms for political parties to build a shared vision and mission in running the country so that with this ideological coalition can strengthen political institutions in the presidential system and prevent fragmentation from happening in the legislature.

\section{Conclusion}

To strengthen the presidential system, in addition to strengthening the function of political parties, the coalition of political parties must also aim strategically based on an ideological coalition model; The coalition was built to fulfill the interests of the vision and ideology of political parties.. The purpose of the ideological coalition is to fulfill people's expectations. An ideological coalition is needed to be a platform for political parties to build a shared vision and mission in organizing the country. The determination of a shared vision in developing Indonesia was formulated at the outsetby carrying out theinterests of the people and fulfilling people's expectations. Ideology, in this case, is the ideology of nationality possessed by political parties. Coalition based on ideology will strengthen the government. The nature of the coalition itself forms a strong, independent (autonomous), and durable government. A strong government can be interpreted as a government capable of creating and implementing its policies without fear of rejection or resistance in parliament. He also emphasized that political parties are required to understand the meaning of coalition government as a mutually indis pensable condition of the multi-party system. It can be said that there is a significant gap in the implementation [coalitions in Indonesia with a multiparty presidential systemadopted. The implication of this is the occurrence of fragmentation in the legislature and the occurrence of a tug of war between the executive and the 
legis lature. Therefore, objectively for further improvement, an ideological coalition model is needed in the life of the nation and state because ideology is the basis of political party platforms to build a shared vision and mission in organizing the country so that this ideological coalition can strengthen institutions.

\section{References}

[1] Achury, S., Scarrow, S. E., Kosiara-Pedersen, K., \& van Haute, E. (2018). The consequences of membership incentives: Do greater political benefits attract different kinds of members? Party Politics. https://doi.org/10.1177/1354068818754603

[2] Almond, G. A., \& Verba, S. (2015). The civic culture: Political attitudes and democracy in five nations. In The Civic Culture: Political Attitudes and Democracy in Five Nations. https://doi.org/10.2307/40198974

[3] Asrinaldi. (2013). Koalisi Model Parlementer dan Dampaknya pada Penguatan Kelembagaan Sistem Presidensial di Indonesia. Jurnal Penelitian Politik. https://doi.org/10.14203/JPP.V10I2.435

[4] Blaydes, L. (2006). Who Votes in Authoritarian Elections and Why? Determinants of Voter Turnout in Contemporary Egypt. Political Science. https://doi.org/papers 2://pub lication/uuid/55AB98F9-56FF-4E2A-9F70-B137632CF9C9

[5] Coller, X., Cordero, G., \& Echavarren, J. M. (2017). Recruitment and selection. In Political Power in Spain: The Multiple Divides between MPs and Citizens. https://doi.org/10.1007/978-3-319-63826-3_5

[6] Dahl, R. A., Shapiro, I., \& Cheibub, J. A. (2003). The democracy sourcebook. In Chemistry. https://doi.org/10.1073/pnas.0703993104

[7] Dinas, E., Riera, P., \& Roussias, N. (2015). Staying in the First League: Parliamentary Representation and the Electoral Success of Small Parties. Political Science Research and Methods. https://doi.org/10.1017/psrm.2014.38

[8] Fassin, D. (2007). Humanitarianism as a politics of life. Public Culture. https://doi.org/10.1215/08992363-2007-007

[9] Golder, M., \& Stramski, J. (2010). Ideological congruence and electoral institutions . American Journal of Political Science. https ://doi.org/10.1111/j.1540- 5907.2009.00420.x

[10] Hampson, F. O., Held, D., McGrew, A., Goldblatt, D., \& Perraton, J. (1999). Global Transformations: Politics, Economics, and Culture. International Journal. https://doi.org/10.2307/40203424

[12] Hess, D. J. (2018). Energy democracy and social movements: A multi-coalition perspective on the politics of sustainability transitions. Energy Research and Social Science. https://doi.org/10.1016/j.ers s.2018.01.003

[13] Hopkin, J. (2001). A 'southern model' of electoral mobilization? Clientelism and electoral politics in Spain. West European Politics. https://doi.org/10.1080/01402380108425420

[14] Keefer, P., \& Vlaicu, R. (2008). Democracy, credibility, and clientelism. Journal of Law, Economics, and Organization. https://doi.org/10.1093/jleo/ewm054

[15] Khan, M. H. (2005). Markets, states and democracy: Patron-client networks and the case for democracy in developing countries. Democratization. https://doi.org/10.1080/13510340500322157 
[16] Kim, H., BinghamPowell, G., \& Fording, R.C. (2010). Electoral systems, party systems, and ideological representation: An analysis of distortion in western democracies. Comparative Politics. https://doi.org/10.5129/001041510X12911363509477

[17] Kitschelt, H. (2000). Citizens, politicians, and party cartellization: Political representation and statefailure in post-industrial democracies. European Journal of Political Research. https://doi.org/10.1111/1475-6765.00508

[18] Lindsey, T. (2001). The criminal state: Premanisme and the New Order. In Indonesia Today: Challenges of History.

[19] Mayne, Q., \& Hakhverdian, A. (2017). Ideological Congruence and Citizen Satisfaction: Evidence From 25 Advanced Democracies. Comparative Political Studies. https://doi.org/10.1177/0010414016639708

[20] McGann, A. J. (2002). The advantages of ideological cohesion: A model of constituency representation and electoral competition in multi-party democracies. Journal of Theoretical Politics. https://doi.org/10.1177/095169280201400104

[21] Villarreal, A. (2002). Political competition and violence in Mexico: Hierarchical social control in local patronage structures. American Sociological Review. https://doi.org/10.2307/3088942 